\title{
CORRECTION
}

\section{Correction to: Examining the usability of touchscreen gestures for adults with DS}

\author{
Doris Cáliz $^{1}$ (1) Ployplearn Ravivanpong ${ }^{1}$ - Andrea Schankin ${ }^{2}$ - Janio Jadán-Guerrero ${ }^{3}$. Washington Caraguay ${ }^{4}$. \\ Leonardo Arellano 5
}

Published online: 12 June 2021

(c) The Author(s), under exclusive licence to Springer Nature Switzerland AG part of Springer Nature 2021

\section{Correction to: \\ Journal of Reliable Intelligent Environments https://doi.org/10.1007/s40860-020-00122-1}

It is important to clarify that the Universidad Espiritu Santo has invested and fully participated in the research and that therefore the paper belongs to it. There is an error in the affil-

The original article can be found online at https://doi.org/10.1007/ s40860-020-00122-1.

\section{Doris Cáliz \\ caliz@teco.edu \\ Ployplearn Ravivanpong \\ ravivanpong@teco.edu \\ Andrea Schankin \\ andrea.schankin@fom.de \\ Janio Jadán-Guerrero \\ janiojadan@uti.edu.ec \\ Washington Caraguay \\ wcaraguay@uees.edu.ec \\ Leonardo Arellano \\ larellano@ute.edu.ec}

1 TECO Department Pervasive Computing Systems, Karlsruhe Institute of Technology, Vincenz-Prießnitz-Straße 1, 76131 Karlsruhe, Germany

2 FOM Hochschulzentren, Karlsruhe Institute of Technology, Vincenz-Prießnitz-Straße 1, 76131 Karlsruhe, Germany

3 Centro de Investigación en Mecatrónica y Sistemas Interactivos (MIST), Universidad Tecnológica Indoamérica Carrera de Ingeniería en Ciencias de La Computación, Av. Machala y Sabanilla, 170301 Quito, Ecuador

4 Facultad de Sistemas y Telecomunicaciones, Universidad Espíritu Santo, Km 2.5 Via Samborondon, Guayaquil, Ecuador iation where the Technical University Espiritu Santo appears since this university has no relationship with the research.

Publisher's Note Springer Nature remains neutral with regard to jurisdictional claims in published maps and institutional affiliations.

5 Dirección de Tecnologías de La Información y Comunicación (DTIC) Rumipamba y Bourgeois, Universidad UTE, 170147 Quito, Ecuador 